\title{
МЕСТО ЛИНГВОСТРАНОВЕДЧЕСКИХ ЗНАНИЙ В ПОДГОТОВКЕ УЧИТЕЛЕЙ КИТАЙСКОГО ЯЗЫКА В РОССИИ
}

\section{THE PLACE OF LINGUISTIC AND AREA KNOWLEDGE IN CHINESE TEACHER TRAINING IN RUSSIA}

\section{O. Anisova}

Summary: The modern approach to the professional training of Chinese teachers who are ready for intercultural communication is based on the generally recognized fact of the inextricable link between language and culture. This article examines in detail the emergence and development of the linguistic and regional component in the system of linguistic education. Based on the analysis carried out, two main functions of linguistic and regional studies have been identified: linguistic and methodical. In addition, the study of scientific works showed that in modern linguodidactics there are two approaches to teaching linguistic and regional studies: social and linguistic. In this research, the author tried to summarize and systematize the available information about the object under consideration and to determine its place in the process of professional training of teachers of the Chinese language.

Keywords: professional education, Chinese teacher training, linguistic knowledge, background knowledge, intercultural communication, competence approach.

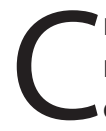
каждым годом Китай все сильнее укрепляет свои позиции на мировой арене - становится страной с потенциалом развитой экономикой, образование в КНР привлекает студентов со всего мира, а также конкурентоспособные научно-технические достижения. Именно по этой причине многие студенты при выборе будущей профессии останавливаются на той, которая так или иначе связана с изучением китайского языка. В связи с этим в России становятся все более востребованными эффективные системы профессиональной подготовки тех, кто будет осуществлять образовательный процесс по данным направлениям и выпускать специалистов готовых к межкультурному взаимодействию. Анализ литературы показал, что в нашей стране сложились определённые предпосылки для исследования профессиональной подготовки учителей китайского языка способных к межкультурному общению (В.И. Богословский, О.С. Кошелева, К.Н. Тишкова и др. исследователи).

Современные условия образовательных учреждений в нашей стране складываются таким образом, что становится необходимым при разработке учебных программ формировать требования к выпускнику в виде универсальных (УК), общеобразовательных (ОК) и професси-
Анисова Оксана Леонидовна

К.п.н., дочент, Московский городской педагогический университет, г. Москва anisovaok@gmail.com

Аннотация: Современный подход профессиональной подготовки учителей китайского языка готовых к межкультурному общению основывается на общепризнанном факте неразрывной связи языка и культуры. В данной статье подробно рассматривается возникновение и развитие лингвострановедческого компонента в системе лингвистического образования. На основе проведенного анализа выделены две основные функции лингвострановедения: лингвистическая и методическая. Кроме того, изучение научных работ показал, что в современной лингводидактике выделяют два подхода к обучению лингвострановедения: социальный и лингвистический. В проделанном исследовании автор попытался обобщить и систематизировать имеющиеся сведения относительно рассматриваемого объекта и определить его место в процессе профессиональной подготовки учителей китайского языка.

Ключевые слова: профессиональное образование, подготовка учителей китайского языка, лингвострановедческие знания, фоновые знания, межкультурное общение, компетентностный подход.

ональных компетенций (ПК), а также дополнительных профессионально-специализированных компетенций (ПСК).

Вместе с тем, главной целью подготовки учителя со знанием китайского языка, как и любого другого, является формирование компетенции межкультурного общения, которая предполагает готовность вести диалог, учитывая понимание особенностей своей и чужой культуры, умение ориентироваться в языковой картине мира собеседника, его социальном статусе, в межкультурных различиях, а также использование различных языковых форм. Данная компетенция является комплексной. Исследование ее содержания и компонентов можно найти в работах Н.Н. Васильевой, В.А. Масловой, Е.Г. Таревой, А.В. Третьяковой, А.П. Садохина, Н.В. Черняк и других. На основе данных работ становится очевидным, что межкультурная компетентность представляет собой совокупность языковых, социокультурных, лингвопсихологических, лингвострановедческих и других знаний.

Современная методическая литература определяет термин лингвострановедения как «аспект в практическом курсе иностранного языка и учебная дисциплина в 
курсе методики его преподавания» [1, 205].

В данном контексте лингвострановедческие знания можно соотнести с формированием ОК-4 «Способность к коммуникации в устной и письменной формах на русском и иностранном языках для решения задач межличностного и межкультурного взаимодействия» и УК-5 «Способность воспринимать межкультурное разнообразия общества в социально-историческом, этическом и философском контекстах», а также ПСК-2 «Способность фонетически, грамматически, лексически, стилистически правильно излагать свои мысли на иностранном языке в устной и письменной форме» [13].

Основателями понятия лингвострановедения в российской методике обучения языку принято считать филологов русского языка В.Г. Костомарова и Е.М. Верещагина, которые определяли данную область знаний как важную составляющую при обучении иностранцев русскому языку, имеющую огромное влияние на формирование коммуникативной компетенции для решения образовательных и воспитательных задач в процессе развития вторичной языковой личности. С точки зрения лингводидактики при таком подходе становится возможным реализовать кумулятивную функцию языка, а также постепенно проводить аккультурацию обучающегося.

Из этого следует, что изучение языка с использованием страноведческого материала первоначально выполняет лингводидактическую функцию, направленную на поиск эффективных методов знакомство студентов с языковыми и культурными реалиями страны изучаемого языка в процессе его овладения.

Проанализировав исследования В.П. Белянина, Д. Мацумото, Л.В. Щербы и других, а также уточнив содержание термина с точки зрения его методической составляющей, позволяет говорить о том, что ни одну культуру невозможно полностью постичь без понимания её языка, равно как и наоборот.

В свою очередь А.Н. Щукин рассматривает лингвострановедение как «страноведчески ориентированную лингвистику, изучающую иностранный язык в сопоставлении с родным. При этом объектом рассмотрения выступает язык как носитель культуры изучаемого языка» $[12,219]$.

В этом контексте становится очевидным неизбежное взаимопроникновение двух культур, то есть происходит познание иных культурных реалий через свои, а связующим звеном в этом будет являться изучаемый язык.

Таким образом, на основании вышеизложенного можно утверждать, что лингвострановедческий матери- ал в процессе обучения китайского языка выполняет как лингвистические, так и методические функции.

В процессе межкультурного общения важно не только пользоваться грамматическими и лексическими навыками, но и уметь их употреблять в контексте привычных для собеседника реалиях, то есть применять фоновые знания. В этом случае явно проявляется лингвистическая функция лингвострановедения и тогда его главной целью можно определить изучение языковых элементов китайского языка с точки зрения культурных особенностей, которые находят свое отражение в лакунах, фразеологизмах, коннотативной и фоновой лексике, в речевом этикете, а также в интонации, мимике и жестах, свойственных только носителям изучаемого языка и культуры.

Что касается методической функции, то она направлена главным образом, на формирование коммуникативной компетенции, которая предполагает умение адекватно реагировать в новых социальных реалиях, владеть культурными нормами, знание обычаев и традиций Китая. Поэтому при отборе лингвострановедческого материала необходимо учитывать все перечисленные аспекты.

Отсюда следует, что в процесс профессиональной подготовки специалистов со знанием китайского языка способных к межкультурному общению необходимо включать лингвострановедческий компонент. При этом главной мотивационной составляющей будет являться желание поехать в страну, где говорят на этом языке и общаться с её представителями. Важно учитывать и то, что межкультурное взаимодействие на профессиональном уровне предполагает не только официальные встречи, но и общение в бытовых ситуациях, поэтому при выборе учебного материала следует охватывать все стороны жизни людей и моделировать предполагаемые формы коммуникации.

Вслед за В.А. Масловой важно отметь, что лингвострановедение является комплексной дисциплиной, включающей рассмотрение исторических, философских, социологических, политических и других аспектов, без рассмотрения которых невозможно полное представление о материальных и духовных ценностях изучаемой нации. «Язык теснейшим образом связан с культурой: он прорастает в нее, развивается в ней и выражает ее. Если традиционный способ осмысления проблемы взаимодействия языка и культуры заключается в попытке решить лингвистические задачи, используя некоторые представления о культуре», то есть и способы, «с помощью которых язык воплощает в своих единицах, хранит и транслирует культуру» $[7,9]$.

Таким образом, вышеизложенное свидетельствует о 
том, что лингвострановедческая компетенция будущих учителей китайского языка подразумевает способность осуществлять межкультурное общение, основанное не только на знаниях лексических единиц, содержащих национальный компонентом, но и умениях адекватного их применения в ситуациях взаимодействия с представителями китайской нации, а также умениях использовать фоновые знания, чтобы исключить возможность быть непонятым.

Кроме того, формирование и развитие лингвострановедческой компетенции будущих специалистов является средством и результатом системного подхода, поэтому следует отметить, что после определения конечной цели лингвострановедения (то есть выделение компетенций, которые должны сформироваться в результате освоения дисциплины), можно говорить о ее содержательной стороне. Поэтому, как отмечает Гальскова Н.Д., «лингвострановедческая компетенция призвана обеспечить коммуникативную компетенцию, что предполагает оперирование аналогичными образами в сознании говорящего и слушающего так, как это происходит при общении между собой носителей одного и того же языка и одной и той же культуры» $[5,98]$. Вместе с тем, лингвострановедческий материал, как правило, вызывает больший интерес у студентов, когда в материале отображены актуальные и злободневные социальные вопросы, чем дидактические тексты, направленные исключительно на отработку лексического и грамматического материала урока. Полноценная насыщенность такого материала лексическими единицами, отображающими культурную самобытность китайской нации, может продемонстрировать их использование в реальной речи, а также в представленном контексте делает его незаменимым с точки зрения дидактической работы с самим материалом. При этом одной из главных задач, которую решают при помощи лингвострановедческого компонента, содержащегося в учебном материале, необходимо считать формирование социолингвистической компетенции, в основу которой заложены фоновые знания, без которых не представляется возможным полноценное общение с представителями китайского языка и культуры. Поэтому очень важно при отборе лингвострановедческого материала отдавать предпочтение аутентичном текстам. В этом случае его можно рассматривать как методически ценным и эффективным средством обучения китайскому языку. В качестве аутентичного лингвострановедческого материала чаще всего используются газетные и журнальные статьи, включая электронные версии.

На основании того факта, что усвоение студентами материала подобного содержания обусловливает формирование у них культурологических знаний, отображающихся в изучаемом языке, а также тесной взаимосвязи лингвострановедения и лингвокультурологии, становится очевидным, что лингвострановедческая компетенция является компонентом лингвокультурологической компетенции. Анализируя работы В.В. Воробьева можно говорить о том, что под лингвокультурологической компетенцией следует понимать хорошее знание всей системы культурных ценностей, выраженных в изучаемом языке, поэтому формирование лингвострановедческой компетенции ведет к развитию лингвокультурологической.

Проведенное исследование свидетельствует о том, что в процессе овладения лингвострановедческим языковым материалом, в частности фразеологическими единицами, лакунами и др., у учащихся формируются историко-фоновые знания, благодаря которым постигается национальное своеобразие образа жизни носителей китайского языка и культуры необходимые для полноценного межкультурного общения $[2,17]$.

Таким образом, можно говорить о прямой взаимосвязи лингвострановедческой компетенции с коммуникативной, социокультурной, а также лингвокультурологической.

В настоящее время в учебную программу подготовки учителей китайского языка, как правило, входит целый курс лингвострановедения, однако кроме этого следует обязательно включать лингвострановедческие материалы в рамках других дисциплин, направленных на изучения языка.

Через призму лингводидактики к овладению лингвострановедческими знаниями можно применить два подхода: социальный и лингвистический.

Согласно первому подходу страноведческие знания включают знание географического положения страны, вопросов, связанных с населением, истории экономического развития, образования, социальных проблем и др. $[6,546]$. При этом обучаемым, как правило, свойственно соотносить новые знания с уже имеющимися о родной национальной культуре. В результате данного подхода студенты получают фоновые знания, при этом важно понимать необходимый объем информации о перечисленных аспектах. Поэтому, по мнению Г.Д. Томахина, следует разделять страноведение и лингвострановедение в системе лингвистического образования. Таким образом, страноведение может быть включено в блок общеобразовательных дисциплин и преподаваться на родном языке, а лингвострановедение в большей степени имеет тесную связь с узкой профессиональной специализацией и большое значение придается не как отдельному предмету, а как комплексной дисциплине по практике изучаемого языка $[11,59]$.

При лингвистическом подходе в процессе овладения лингвострановедческими знаниями педагог решает как 
минимум две главные задачи:

1. Получить информацию о культуре страны изучаемого языка из языковых единиц. При таком подходе доминирующим компонентом дисциплины будет являться не сам язык, а культура.

2. Научить воспринимать языковые единицы изучаемого языка и употреблять согласно тем образам, которые сформированы в сознании носителей китайского языка и культуры. Под образами следует понимать закодированные национальные элементы. Образ, на котором строится смысловое значение слова или фразеологической единицы, возникает у студента поэтапно в процессе формирования навыка употребления языковой или речевой единицы, а затем выстраиваются в семантические группы.

При таком подходе главным объектом изучения лингвострановедения является не культура, а язык, и все силы направлены на формирование лингвострановедческой компетенции, являющейся одной из главных составляющих компетенции межкультурного общения.

Анализ указанных в статье исследовательских работ, позволяет сделать вывод о том, что в процессе подго- товки будущих учителей китайского языка лингвострановедческие знания направлены на формирование коммуникативной, лингвокультурологической, социокультурной компетенций, владение которыми необходимы прежде всего в речевых актах межкультурного общения через адекватное восприятие речи собеседника и аутентичных текстов, рассчитанных на носителей китайского языка и культуры. Вместе с тем лингвострановедение выполняет лингвистическую и методическую функцию.

Таким образом, лингвострановедение можно рассматривать как учебную дисциплину, с одной стороны, направленную на овладение китайским языком, а с другой, дающее определенные сведения о стране и культуре Китая. Поэтому для формирования компетенции межкультурного общения у будущих учителей китайского языка важно понимать, что для того, чтобы обучаемые могли правильно выстраивать тактику и стратегию успешного речевого общения, процесс овладения китайским языком должен включать в себя знакомство с устройством социальной системы страны изучаемого языка, с окружающей действительностью современного Китая и жизненным укладом современного китайского общества.

ЛИТЕРАТУРА

1. Азимов Э.Г., Щукин А.Н. Новый словарь методических терминов и понятий (теория и практика обучения языкам). - М.: Издательство ИКАР, $2009 .-448$ C.

2. Воробьев В.В. Русский язык в диалоге культур. М., «Ладомир», 2006. - 286 с.

3. Воробьева Е.И. Содержание и структура понятия лингвострановедческая компетенция учителя иностранного языка. М., 1999, с 3-6.

4. Гальскова Н.Д, Гез Н.И. Теория обучения иностранным языкам, М., «Академия», 2006, 336 с.

5. Гальскова Н.Д. Современная методика обучения иностранным языкам -М., Аркти-Глосса, 2000, 333 с.

6. Елизарова Г.В. Культура и обучение иностранным языкам. - С-Пб., 2005, 351 с.

7. Маслова В.А. Лингвокультурология: Учеб. пособие для студ. высш. учеб, заведений. - М.: Издательский центр «Академия», 2001. -- 208с.

8. Московкин Л.В., Юрков Е.Е. Коммуникативная компетенция: определение, состав, проблемы обучения. Сборник научных трудов под. Ред. Щукина А.Н. М., Филоматис, 2006, 199 с.

9. Прохоров Ю. Е. Лингвострановедение. Культуроведение. Страноведение: Теория и практика обучения рус.яз. как иностранному : Метод. пособие для студентов-русистов и преподавателей рус. яз. иностранцам / Ю.Е. Прохоров; Ин-т рус. яз. им. А. С. Пушкина. - М.: ИРЯП, 1998. - 108 с.

10. Тарева Е.Г. Система культуросообразных подходов к обучению иностранному языку / Е.Г. Тарева // Язык и культура. 2017. № 40. С. $302-320$.

11. Томахин Г.Д. Реалии - американизмы : Пособие по страноведению: [Для ин-тов и фак. иностр. яз.] / Г.Д. Томахин. - М.: Высш. шк., 1988. - 238 с.

12. Щукин А.Н., Методика преподавания русского языка как иностранного. М.: 2017. - 509 с.

13. Федеральный государственный образовательный стандарт высшего образования, утв. Приказом № 124 Министерством образования и науки РФ от 22.02.2018

(c) Анисова Оксана Леонидовна (anisovaok@gmail.com). 